\title{
Effects of nutrition on digestion efficiency and gaseous emissions from slurry in growing-finishing pigs. I. Influence of the inclusion of two levels of orange pulp and carob meal in isofibrous diets
}

\author{
A. Beccaccia , S. Calvet , A. Cerisuelo , P. Ferrer , \\ P. García-Rebollar ，C. De Blas
}

An experiment was conducted to investigate the effects of increasing the level of two sources of fibrous by-products, orange pulp (OP) and carob meal (CM), in iso-NDF growingfinishing pig diets on nutrient balance, slurry composition and potential ammonia $\left(\mathrm{NH}_{3}\right)$ and methane $\left(\mathrm{CH}_{4}\right)$ emissions. Thirty pigs $(85.4 \pm 12.3 \mathrm{~kg})$ were fed five iso-nutritive diets: a commercial control wheat/barley (C) and four experimental diets including two sources of fibrous by-products (OP and CM) and two dietary levels (75 and $150 \mathrm{~g} / \mathrm{kg}$ ) in a $2 \times 2$ factorial arrangement. After a 14-day adaptation period, faeces and urine were collected separately for 7 days to measure nutrient digestibility and the excretory patterns of $\mathrm{N}$ from pigs ( 6 replicates per diet) housed individually in metabolic pens. For each animal, the derived $\mathrm{NH}_{3}$ and $\mathrm{CH}_{4}$ emissions were measured in samples of slurry over an 11- and 100-day storage periods, respectively. Source and level of the fibrous by-products affected digestion efficiency in a different way as the coefficients of total tract apparent digestibility (CTTAD) for dry matter (DM), organic matter (OM), fibre fractions and gross energy increased with OP but decreased with $\mathrm{CM}(P<0.05)$. Crude protein CTTAD decreased with the inclusion of both sources of fibre, being lower at the highest dietary level. Faecal concentration of fibre fractions increased $(P<0.05)$ with the level of inclusion of $C M$ but decreased with that of $\mathrm{OP}(P<0.01)$. High dietary level for both sources of fibre increased $(P<0.02) \mathrm{CP}$ faecal content but urine $N$ content decreased (from 205 to $168 \mathrm{~g} / \mathrm{kg} \mathrm{DM}, P<0.05$ ) in all the fibre-supplemented compared to $C$ diet. Additionally, the proportions of undigested dietary, water soluble, and bacterial and endogenous debris of faecal $\mathrm{N}$ excretion were not affected by treatments. The initial slurry characteristics did not differ among different fibre sources 


\section{Introduction}

Animal feeding has been recognized as an essential tool for controlling gas emissions from manure in the livestock sector (FAO, 2013). The effectiveness of the nutritional strategies adopted in order to modulate gas production from slurry is based on the effects of diet composition on nutrient digestibility and metabolism, and on the fermentation rates in the hindgut. All these variables can affect slurry characteristics and thus gas emissions (Møller et al., 2004a,b; Dinuccio et al., 2008).

Various nutritional strategies, as the inclusion of fibre sources in feeds, have been proposed in order to mitigate ammonia $\left(\mathrm{NH}_{3}\right)$ emission derived from manure in pig farms. Several works indicate that these effects are depending on the type of fibre used. The addition of low lignified fibrous feedstuffs (as sugar beet pulp or soybean hulls) in pig diets had little effect on total nitrogen (N) excretion, but caused a shift of $\mathbf{N}$ from urine to faeces (Canh et al., 1997; Zervas and Zijlstra, 2002b; Bindelle et al., 2009; Heimendahl et al., 2010; Galassi et al., 2010). Dietary supply of fermentable fibre also reduced faecal and slurry $\mathrm{pH}$ through an increase of volatile fatty acids (VFA) formation in the large intestine, thereby decreasing additionally $\mathrm{NH}_{3}$ emission (Canh et al., 1998a,b). However, it is suggested that the use of more lignified fibre sources (e.g. oat hulls) had no influence on $\mathrm{N}$ partitioning (Zervas and Zijlstra, 2002a; Bindelle et al., 2009); otherwise, it decreases nutrient digestibility and might then modify excreta composition and $\mathrm{NH}_{3}$ emission, although information on this subject is still scarce. In all these works, inclusion of the various types of fibre studied was parallel to an increase of dietary fibre concentration, and therefore the effects of source and level of the ingredients used were confounded.

The effects of livestock nutrition on pig methane $\left(\mathrm{CH}_{4}\right)$ emission have been less studied than those related to $\mathrm{NH}_{3}$. Most of $\mathrm{CH}_{4}$ emissions in pigs are originated during manure storage, as a result of the degradation of organic compounds by methanogenic archaea. They will depend both on the amount and composition of organic matter (OM) excreted. Highly lignified cell wall components of feeds remain undigested and constitute the main energy substrate for $\mathrm{CH}_{4}$ production, and can also increase the excretion of other nutrients in faeces. However, cellulose and lignin have the lowest $\mathrm{CH}_{4}$ potential emissions, whereas undigested lipids and protein have the highest (Angelidaki and Sanders, 2004). In practical conditions, the inclusion of different fibre sources, such as dry distillers grains and solubles, sugar beet pulp or rapeseed meal led to variable effects on the potential for $\mathrm{CH}_{4}$ production from faeces $\left(B_{0}\right)$ and the total $\mathrm{CH}_{4}$ produced per pig (Jarret et al., 2011, 2012). Thus, altering source of dietary fibre can potentially serve to manipulate $\mathrm{CH}_{4}$ emissions from slurry.

In the current study diets were designed to have a similar insoluble fibre content ( $160 \mathrm{~g} \mathrm{NDF} / \mathrm{kg} \mathrm{DM})$, as commercial feeds are typically formulated for a given level of this nutrient. The experiment was conducted to investigate the effects of including in growing-finishing pig diets two levels ( 75 and $150 \mathrm{~g} / \mathrm{kg}$ ) of two sources of fibrous by-products highly available in the Mediterranean area (orange pulp (OP) and carob meal (CM), with a low or high degree of lignification, respectively) on nutrient balance, faecal $\mathrm{N}$ fractionation (dietary, bacterial and endogenous and soluble), slurry composition and potential $\mathrm{NH}_{3}$ and $\mathrm{CH}_{4}$ emissions.

\section{Materials and methods}

\subsection{Animals, diets and experimental design}

Thirty finishing male pigs, progeny of Danish Duroc $\times$ (Landrace $\times$ Large White) divided into three series (batches) of 10 animals each were used subsequently in this study. Average and standard deviation of body weight of pigs in batches 1,2 and 3 at allocation in metabolism pens were $85.6( \pm 2.44), 102( \pm 3.57)$ and $114( \pm 2.93) \mathrm{kg}$, respectively. Five experimental feeds were designed: a control diet (C) formulated with the most common ingredients used at present in commercial diets for growing-finishing pigs (wheat, barley and soybean meal) and another four diets including two levels (75 or $150 \mathrm{~g} / \mathrm{kg}$ ) of OP or CM in replacement of barley grain. In order to maintain a constant neutral detergent fibre (aNDFom), net energy, protein and essential amino acid level among diets, lard, soybean meal and synthetic amino acids were added to the feeds including fibrous by-products. Essential nutrients were formulated according to the recommendations of FEDNA (2006) for fattening pigs. The chemical composition of the OP and CM samples and the ingredient and chemical composition of the experimental diets is shown in Tables 1-3, respectively. As shown, a higher concentration of acid detergent fibre (ADFom), acid detergent lignin (ADL), ether extract (EE) and sugars resulted in feeds containing fibrous by-products, especially in CM based diets. Instead, soluble fibre content was greater in OP compared to CM and control diets. 
Table 1

Chemical composition of the fibrous ingredients used in the experimental diets ( $\mathrm{g} / \mathrm{kg}$, as fed basis).

\begin{tabular}{|c|c|c|}
\hline & Orange pulp & Carob meal \\
\hline Dry matter & 907 & 867 \\
\hline Ash & 60.9 & 30.7 \\
\hline Crude protein & 52.6 & 42.5 \\
\hline NDICPa & 27.1 & 15.7 \\
\hline Ether extract & 16.0 & 8.0 \\
\hline Total dietary fibre & 515 & 405 \\
\hline aNDFom & 274 & 353 \\
\hline ADFom & 185 & 317 \\
\hline ADL & 24.7 & 173 \\
\hline Sugars & 206 & 354 \\
\hline Soluble fibre ${ }^{b}$ & 268 & 68.0 \\
\hline Gross energy (MJ/kg) & 15.8 & 16.6 \\
\hline
\end{tabular}

a Neutral detergent insoluble crude protein.

b Calculated as total dietary fibre minus aNDFom corrected for protein.

The experimental period consisted in a 14-day adaptation period to diets followed by a period of 7 consecutive days in which faeces and urine were collected individually (21 days in total). At the beginning of each trial, pigs were blocked according to live weight, assigned to one of five dietary treatments and placed in conventional pens until Day 9 of the adaptation period. After this period, animals were individually housed in metabolism pens $\left(1.2 \times 2 \mathrm{~m}^{2}\right)$ until the end of the experiment. These pens allowed the measurement of individual feed intake and total and separate collection of faeces and urine. The collection period was divided in two parts to facilitate collections for energy and nutrient balance (Days 1-4) and gaseous emission study (Days 5-7). Feed and water were provided ad libitum during the adaptation and collecting periods. Feed was provided in dry form (pelleted). Pigs were individually weighed at the beginning of the adaptation period, at allocation in metabolism pens (Day 9 of experiment) and at the end of the experiment. Feed consumption was measured per pen until Day 9 of the experimental period and individually until the end of the experiment. Water consumption was measured individually during the collection period. Water was supplied by individual tanks and water spillage was collected and considered to calculate real water consumption.

\subsection{Nutrient balance trial and sample preparation}

During the energy and nutrient balance (4 days), total urine and faeces excreted per animal were collected daily in separate buckets, weighed and stored in a chamber at $4^{\circ} \mathrm{C}$ until the end of the collection period. To avoid nitrogen losses due to $\mathrm{NH}_{3}$ volatilization, urine was collected under sulphuric acid ( $120 \mathrm{~mL}$ of $\mathrm{H}_{2} \mathrm{SO}_{4}$ at $10 \%$ per bucket and day). Upon final collection the faeces and urine were pooled per pig, mixed, subsampled and stored at $-20^{\circ} \mathrm{C}$ until laboratory analyses were performed. During the next 3 days, urine and faeces were collected in a similar way, but without any addition of sulphuric acid to urine. At the end of the collection period slurries were reconstituted by mixing urine and faeces from each animal in the same proportion as excreted. A part of these slurries was used in fresh for $\mathrm{pH}$ and $\mathrm{NH}_{3}$ emission measurements and another one was subsampled and frozen $\left(-20^{\circ} \mathrm{C}\right)$ for $B_{0}$ and slurry characteristics determination.

Table 2

Ingredient composition of the experimental diets $(\mathrm{g} / \mathrm{kg})$.

\begin{tabular}{|c|c|c|c|c|c|}
\hline & Control & OP75 & OP150 & $\mathrm{CM} 75^{\mathrm{a}}$ & CM150 \\
\hline Barley grain & 400 & 301 & 202 & 282 & 163 \\
\hline Wheat grain & 450 & 450 & 450 & 450 & 450 \\
\hline Soybean meal, $42.5 \%$ CP & 103 & 122 & 141 & 132 & 161 \\
\hline Orange pulp & 0 & 75.0 & 150 & 0 & 0 \\
\hline Carob meal & 0 & 0 & 0 & 75 & 150 \\
\hline Lard & 11.9 & 20.5 & 29.0 & 27.5 & 43.0 \\
\hline Calcium carbonate & 11.6 & 8.00 & 4.39 & 10.1 & 8.64 \\
\hline Sodium chloride & 3.89 & 3.78 & 3.67 & 3.84 & 3.79 \\
\hline Monocalcium phosphate & 8.76 & 9.42 & 10.1 & 9.37 & 10.0 \\
\hline L-Lysine HCL & 4.07 & 3.87 & 3.67 & 3.69 & 3.32 \\
\hline DL-Methionine & 0.59 & 0.61 & 0.62 & 0.58 & 0.57 \\
\hline L-Threonine & 1.13 & 1.11 & 1.10 & 1.11 & 1.08 \\
\hline Premix ${ }^{b}$ & 5.00 & 5.00 & 5.00 & 5.00 & 5.00 \\
\hline
\end{tabular}

a OP75 $=75 \mathrm{~g} / \mathrm{kg}$ orange pulp; OP $150=150 \mathrm{~g} / \mathrm{kg}$ orange pulp; CM75 = 75 g/kg carob meal; CM150=150g $/ \mathrm{kg}$ carob meal.

b Vitamin and mineral premix supplied per kg complete diet:5000 IU of vitamin A; 1000 IU of vitamin D3; 3 mg of vitamin B2; 20 mg of vitamin B12; $10 \mathrm{mg}$ of niacin; $4 \mathrm{mg}$ of pantothenic acid; $48 \mathrm{mg}$ of betaine; $30 \mathrm{mg}$ of manganese oxide; $110 \mathrm{mg}$ of zinc oxide; $10 \mathrm{mg}$ of copper sulphate; $0.75 \mathrm{mg}$ of potassium iodide; $0.1 \mathrm{mg}$ sodium selenite: $90 \mathrm{mg}$ of iron carbonate. 
Table 3

Chemical composition of the experimental diets ( $\mathrm{g} / \mathrm{kg}$, as fed basis).

\begin{tabular}{|c|c|c|c|c|c|}
\hline & Control & OP75 & $\mathrm{OP} 150^{\mathrm{a}}$ & $\mathrm{CM}_{75^{\mathrm{a}}}$ & CM150 \\
\hline \multicolumn{6}{|l|}{ Analyzed } \\
\hline Dry matter & 912 & 902 & 903 & 895 & 899 \\
\hline Ash & 51.8 & 53.0 & 54.3 & 52.1 & 51.0 \\
\hline Crude protein & 158 & 156 & 154 & 153 & 157 \\
\hline $\mathrm{NDICP}^{\mathrm{b}}$ & 21.4 & 26.7 & 21.2 & 23.8 & 20.8 \\
\hline Ether extract & 43.0 & 53.3 & 62.9 & 59.2 & 72.1 \\
\hline Total dietary fibre & 194 & 214 & 234 & 200 & 212 \\
\hline aNDFom & 154 & 165 & 158 & 164 & 161 \\
\hline ADFom & 45.6 & 52.3 & 56.3 & 61.0 & 75.4 \\
\hline ADL & 8.0 & 9.0 & 10.7 & 18.9 & 33.9 \\
\hline Soluble fibre ${ }^{c}$ & 61.2 & 75.9 & 97.3 & 60.1 & 71.4 \\
\hline Gross energy (M//kg) & 16.8 & 16.9 & 17.0 & 16.9 & 17.4 \\
\hline \multicolumn{6}{|l|}{ Calculated $^{\mathrm{d}}$} \\
\hline Net energy (MJ/kg DM) & 9.83 & 9.83 & 9.83 & 9.83 & 9.83 \\
\hline Calcium & 6.80 & 6.65 & 6.50 & 6.65 & 6.50 \\
\hline Digestible phosphorous & 2.80 & 2.91 & 3.02 & 2.90 & 3.00 \\
\hline Sodium & 1.70 & 1.70 & 1.70 & 1.70 & 1.70 \\
\hline Chlorine & 3.92 & 3.75 & 3.58 & 3.81 & 3.70 \\
\hline \multicolumn{6}{|l|}{ Ileal digestible amino acids ${ }^{\mathrm{d}}$} \\
\hline Lysine & 8.21 & 8.18 & 8.16 & 8.14 & 8.07 \\
\hline Methionine & 2.55 & 2.52 & 2.50 & 2.50 & 2.45 \\
\hline Total sulphur amino acids & 5.08 & 4.97 & 4.86 & 4.92 & 4.76 \\
\hline Threonine & 5.20 & 5.20 & 5.20 & 5.20 & 5.20 \\
\hline Tryptophan & 1.54 & 1.53 & 1.52 & 1.53 & 1.52 \\
\hline Valine & 5.86 & 5.81 & 5.76 & 5.78 & 5.70 \\
\hline Isoleucine & 4.87 & 4.90 & 4.92 & 4.92 & 4.97 \\
\hline
\end{tabular}

a $\mathrm{OP75}=75 \mathrm{~g} / \mathrm{kg}$ orange pulp; OP150 $=150 \mathrm{~g} / \mathrm{kg}$ orange pulp; $\mathrm{CM} 75=75 \mathrm{~g} / \mathrm{kg}$ carob meal; $\mathrm{CM} 150=150 \mathrm{~g} / \mathrm{kg}$ carob meal.

b Neutral detergent insoluble crude protein.

c Calculated as TDF minus aNDFom corrected for NDICP.

d Values calculated according to FEDNA (2010).

\subsection{Feed and effluents' chemical analysis}

Feeds and faeces from the nutrient balance period were analyzed for dry matter (DM), ash, total dietary fibre (TDF), aNDFom, ADFom and ADL, EE, gross energy (GE), nitrogen (N) and neutral detergent insoluble crude protein (NDICP) concentration. Additionally, faecal N fractionation into undigested and soluble N was determined. Dry matter (930.15), ash (923.03), and TDF (985.29) contents of feeds and faeces were carried out according to AOAC (2000) procedures. Concentration of aNDFom, ADFom and ADL were determined sequentially by using the filter bag system (Ankom Technology Corp., Macedon, NY, USA) according to Mertens (2002), AOAC (2000; procedure 973.187) and Van Soest et al. (1991), using heat stable amylase (A3306, Sigma-Aldrich, Tres Cantos, Spain), and expressed without residual ash. The contents in soluble fibre were estimated from difference between TDF and aNDFom corrected by CP content in the residue. The contents in hemicelluloses and cellulose were estimated, respectively, from the differences between aNDFom and ADFom and ADFom-ADL concentrations. Feed and faeces were defatted with petroleum ether prior to fibre analysis. Ether extract content was determined by AOAC methods (920.39). Gross energy concentration was measured in an isoperibol bomb calorimeter (Parr 1356, Parr Instruments Co., Moline, IL, USA). Total N was measured by combustion (method 986.06; AOAC, 2000) using a Leco equipment (model FP-528, Leco Corporation, St. Joseph, MI, USA) and crude protein (CP) estimated as N content $\times 6.25$. The proportion of NDICP in feed and faeces samples was determined following the standardized procedures of Licitra et al. (1996), by analysing the $\mathbf{N}$ content (combustion method) in the NDF residues. Nitrogen fractionation of faecal samples was carried out according to the procedure suggested by Kreuzer et al. (1989), by steam distillation (APHA, 2005) using an automatic analyser ( $2300 \mathrm{Kjeltec}$, Foss Analytical, Hilleroed, Denmark). In this procedure, total faecal $\mathrm{N}$ content is separated after centrifugation between soluble (WSN) and sedimented N, and the bacterial and endogenous debris (BEDN) calculated from the difference between the $\mathrm{N}$ sedimented and the undigested $\mathrm{N}$ (UDN) estimated from NDICP values.

Urine was analyzed for DM, N and GE content. The urine was freeze-dried to obtain its DM content and mixed with benzoic acid before GE analysis to make sure that all sample was burned. Total $\mathrm{N}$ was determined by steam distillation (APHA, 2005) using an automatic analyser (2300 Kjeltec, Foss Analytical, Hilleroed, Denmark).

Immediately after reconstitution, slurry $\mathrm{pH}$ was measured by duplicate with a glass electrode (Crison Basic 20+, Crison, Barcelona, Spain) and samples were taken to analyze DM, ash, total ammonia N (TAN), total Kjeldahl N (TKN) and VFA concentration. The DM and ash content was analyzed using the same equipment and following the same methodology than that used in faeces analyses. The TAN and TKN were determined by steam distillation (APHA, 2005) using an automatic analyser (2300 Kjeltec, Foss Analytical, Hilleroed, Denmark). To avoid N volatilization, the subsample used for TAN analyses was acidified with $\mathrm{HCl}$ immediately after reconstitution. Volatile fatty acids concentration was determined by gas chromatography 
equipped with a flame ionization detector (HP 68050 series Hewlet Packard, USA) following the method described by Jouany (1982) with the addition of an internal standard (4-metil valeric).

\subsection{Gaseous emissions monitoring}

Ammonia emission was measured from fresh samples of reconstituted slurry over 11 days using an ammonia trap system similar to that described by Ndegwa et al. (2009). Slurry samples of $0.5 \mathrm{~kg}$ from each animal $+50 \mathrm{~mL}$ of distilled water to prevent surface crust formation, were placed in a $1 \mathrm{~L}$ closed container and maintained at $25^{\circ} \mathrm{C}$ in a thermostatic water bath (Selecta, Spain). Containers were connected to an air pump which extracted air at a constant airflow rate of $1.2 \mathrm{~L} / \mathrm{min}$. During 11 consecutive days, the air was forced to pass through two absorption flasks (impingers) in serial containing $100 \mathrm{~mL}$ of sulphuric acid $0.1 \mathrm{~N}$. The acid solution was replaced daily during the first 5 days, and every $48 \mathrm{~h}$ until the end of the assay (Day 11). The $\mathrm{NH}_{3}$ trapped in the impingers was analyzed following $4500 \mathrm{NH}_{3}-\mathrm{D}$ procedure (APHA, 2005) using a detection electrode (Orion High Performance $\mathrm{NH}_{3}$ Electrode, model 9512HPBNWP, Thermo Scientific, USA). The cumulative $\mathrm{NH}_{3}$ emission for each sample was calculated by adding the amount retained daily in the flasks during the experimental test.

Biochemical $\mathrm{CH}_{4}$ potential from slurry was measured as the cumulative $\mathrm{CH}_{4}$ production per gram of $\mathrm{OM}$ in a batch assay, using $120 \mathrm{~mL}$ glass bottles incubated at a mesophilic range $\left(35 \pm 1^{\circ} \mathrm{C}\right)$ for 100 days, following the methodology described by Angelidaki et al. (2009). Anaerobic inoculum was collected from an anaerobic digester of the Universitat Politècnica de València that treated pig slurry, and pre-incubated during 15 days at $35^{\circ} \mathrm{C}$ in order to deplete the residual biodegradable organic material (degasification). A mixture of pooled slurry and inoculum was made to obtain an inoculum to substrate ratio of 1 on OM basis. Slurry samples from each animal were tested by triplicate. Additionally, three blank bottles containing only anaerobic inoculum were also used in order to determine its endogenous $\mathrm{CH}_{4}$ production. This was subtracted from the $\mathrm{CH}_{4}$ produced by the slurry on each biogas sampling day. After filling, each bottle was sealed with butyl rubber stoppers and aluminium crimps and the headspace was flushed with pure $\mathrm{N}_{2}$ for $2 \mathrm{~min}$. During incubation, biogas volume in each bottle was regularly monitored (from 1 to 10 days depending on biogas production) by pressure measurement of the headspace using a manometer (Delta Ohm, HD 9220, Italy). Methane concentration in the biogas was further analyzed using a Focus Gas Chromatograph (Thermo, Milan, Italy) equipped with a split/splitless injector and a flame ionization detector.

\subsection{Statistical analysis}

Animal was the experimental unit for all the traits studied. The whole data set derived from the five dietary treatments was analyzed in a one factor ANOVA as a completely randomized design, with trial series, type of diet and its interaction as main effects by using PROC GLM of SAS (2008). The effects of type of diet were analyzed as a factorial arrangement by using orthogonal contrasts with source and level of inclusion of fibrous feeds as main factors. Contrasts of each of the experimental treatments against the control diet were done by using a Dunnett test. Specific contrasts among means were done when needed. Cumulated $\mathrm{CH}_{4}$ evolution was analyzed by a repeated measures model using PROC MIXED of SAS (2008). Sources of variation included treatment, time, and the treatment $\times$ time interaction. The random variable was pig within treatment. Variables were analyzed subjected to three covariance structures: compound symmetry, compound symmetry heterogeneous and autoregressive order 1. Using the largest Akaike information criterion and Schwarz Bayesian criterion, the compound symmetry was the structure that fitted the model best.

\section{Results}

The influence of trial series and of its interactions with dietary treatments on any of the traits studied was not significant and it is not shown.

\subsection{Coefficient of total tract apparent digestibility (CTTAD)}

An interaction was observed for feed intake $(P=0.045)$ indicating that it decreases with the level of fibre in diets with OP while increases with the level of fibre in diets with CM (C: $2.67 \mathrm{~kg} / \mathrm{day} ;$ OP75: $2.62 \mathrm{~kg} / \mathrm{day} ;$ OP150: $2.52 \mathrm{~kg} / \mathrm{day} ;$ CM75: $2.55 \mathrm{~kg} /$ day; CM150: $3.00 \mathrm{~kg} /$ day; SEM: 0.143 ). The interaction between source and level of fibrous by-products added had a significant impact on DM, OM and gross energy digestion efficiency, as these CTTAD values increased with OP but decreased with CM inclusion $(P<0.05$, see Table 4). Faecal digestibilities of TDF, aNDFom, ADFom, ADL and cellulose digestibility averaged $0.661,0.548,0.366,0.254$ and 0.420 , respectively, in all fibre by-products supplemented feeds and varied in parallel to changes in DM digestibility. Hemicellulose CTTAD values were high ( 0.666 as average), tending $(P=0.08)$ to increase in OP diets, but were not affected by the level of inclusion of fibrous by-products. Soluble fibre digestibility values were also high ( 0.880 as average) and did not differ among sources and levels of fibre. Otherwise, CP digestibility was lower in CM than in OP diets ( 0.798 vs. $0.824 ; P=0.003)$ and at the highest levels of inclusion of both fibrous ingredients $(0.803$ vs. 0.820 ; $P=0.03$ ).

When comparing with respect to $C$ diet, inclusion of both types of fibrous by-products decreased DM, OM and CP CTTAD values, although the decrease was lesser, and sometimes non-significant, in diets including $150 \mathrm{~g} / \mathrm{kg}$ of OP. Otherwise, the 
Table 4

Effect of source (S) and level (L) of fibrous byproducts on the apparent total tract digestibility coefficients and energy balance of the experimental diets.

\begin{tabular}{|c|c|c|c|c|c|c|c|c|c|}
\hline & \multicolumn{6}{|c|}{ Treatments $^{a}$} & \multicolumn{3}{|c|}{ Significance } \\
\hline & Control & OP75 & OP150 & CM75 & CM150 & $\mathrm{SEM}^{\mathrm{b}}$ & $S$ & $L$ & $S \times L$ \\
\hline Dry matter ${ }^{c, d, e}$ & 0.868 & 0.852 & 0.868 & 0.835 & 0.820 & 0.005 & $<0.001$ & 0.860 & 0.004 \\
\hline Organic matter ${ }^{c, d, e}$ & 0.884 & 0.868 & 0.880 & 0.852 & 0.835 & 0.004 & $<0.001$ & 0.402 & 0.002 \\
\hline Crude protein ${ }^{c, d, e, g}$ & 0.866 & 0.828 & 0.820 & 0.812 & 0.785 & 0.073 & 0.003 & 0.031 & 0.230 \\
\hline Ether extract ${ }^{\mathrm{f}, \mathrm{h}}$ & 0.746 & 0.757 & 0.788 & 0.772 & 0.788 & 0.009 & 0.448 & 0.025 & 0.447 \\
\hline Total dietary fibreg & 0.630 & 0.674 & 0.745 & 0.640 & 0.587 & 0.017 & $<0.001$ & 0.616 & 0.006 \\
\hline Soluble fibre ${ }^{\mathrm{i}}$ & 0.883 & 0.940 & 0.926 & 0.931 & 0.883 & 0.028 & 0.408 & 0.324 & 0.578 \\
\hline aNDFon $^{\mathrm{d}, \mathrm{e}, \mathrm{g}}$ & 0.572 & 0.577 & 0.645 & 0.523 & 0.447 & 0.009 & $<0.001$ & 0.654 & $<0.001$ \\
\hline ADFom $^{\mathrm{e}, \mathrm{g}}$ & 0.368 & 0.395 & 0.535 & 0.317 & 0.218 & 0.019 & $<0.001$ & 0.297 & $<0.001$ \\
\hline ADL & 0.216 & 0.172 & 0.398 & 0.332 & 0.115 & 0.051 & $<0.007$ & 0.060 & 0.032 \\
\hline Hemicellulosesi & 0.656 & 0.662 & 0.703 & 0.650 & 0.650 & 0.017 & 0.083 & 0.252 & 0.252 \\
\hline Cellulose $^{\mathrm{c}, \mathrm{f}, \mathrm{g}, \mathrm{k}}$ & 0.368 & 0.438 & 0.542 & 0.400 & 0.303 & 0.015 & $<0.001$ & 0.749 & $<0.001$ \\
\hline Gross energy ${ }^{\mathrm{d}, \mathrm{e}}$ & 0.872 & 0.855 & 0.863 & 0.835 & 0.820 & 0.004 & $<0.001$ & 0.451 & 0.016 \\
\hline$(\mathrm{DE}-\mathrm{UE}) / \mathrm{DE}^{\mathrm{h}, 1}$ & 0.975 & 0.972 & 0.969 & 0.973 & 0.973 & 0.002 & 0.093 & 0.558 & 0.250 \\
\hline
\end{tabular}

a $\mathrm{OP} 75=75 \mathrm{~g} / \mathrm{kg}$ orange pulp; OP150 $=150 \mathrm{~g} / \mathrm{kg}$ orange pulp; $\mathrm{CM} 75=75 \mathrm{~g} / \mathrm{kg}$ carob meal; CM $150=150 \mathrm{~g} / \mathrm{kg}$ carob meal.

b Standard error of means $(n=6)$.

c Contrast control vs. OP75 $(P<0.05)$.

d Contrast control vs. CM75 $(P<0.01)$.

e Contrast control vs. CM150 $(P<0.01)$.

${ }^{\mathrm{f}}$ Contrast control vs. CM150 $(P<0.05)$.

$g$ Contrast control vs. OP $150(P<0.01)$.

h Contrast control vs. OP150 $(P<0.05)$.

i Calculated as TDF minus aNDFom corrected for protein.

j Calculated as the difference between NDF and ADF.

${ }^{k}$ Calculated as the difference between ADF and ADL.

1 Proportion of digestible energy not loss in urine.

inclusion of $150 \mathrm{~g} / \mathrm{kg}$ of OP increased while the inclusion of $150 \mathrm{~g} / \mathrm{kg}$ of CM decreased aNDFom and ADFom CTTAD. Moreover, the CTTAD of EE was higher in the treatments with the greatest fibre inclusion levels, in parallel to the higher addition of lard to these diets in order to make them isoenergetic. Energy CTTAD in diets including OP did not differ from $C$ diet, but decreased in diets including $\mathrm{CM}$.

\subsection{Composition of effluents}

According to the digestibility results, the interaction source $x$ type of dietary fibre added was significant $(P<0.05)$ for aNDFom, ADFom and ADL faecal contents expressed on DM basis, as these components decreased with level of inclusion of OP but increased in the case of CM (Table 5). Dry matter and OM concentration in faeces increased only for diet CM150 $(P<0.05$, with respect to any of the other fibrous-added diets). Crude protein faecal concentrations increased $(P<0.02)$ and hemicellulose decreased $(P<0.001)$ with level of fibrous by-products addition in both fibrous sources. Otherwise, OP treatments tended to have a greater $C P(P=0.06)$ and hemicellulose $(P<0.001)$ and a lesser $(P<0.02)$ NDICP and gross energy concentration in faeces than $\mathrm{CM}$ treatments. The soluble fibre content in faeces was low in all treatments but tended $(P<0.109)$ to increase with the level of $\mathrm{OP}$ and $\mathrm{CM}$ in diets. No significant effects of source and level of fibrous by-products were detected neither on urine DM and $\mathrm{N}$ content. However, a trend $(P=0.093)$ was observed for greater relative energy urine losses in OP than in CM diets.

The comparison of results with $C M$ versus the $C$ diet shows a decrease of hemicellulose and cellulose contents in faecal $\mathrm{DM}$, but an increment in those of OM, CP, NDICP, ADFom and ADL in CM diets, with no significant differences in those of DM, $\mathrm{EE}$, and aNDFom concentrations. The differences were smaller in the case of OP than in CM diets, as a greater content of EE, $\mathrm{CP}$ and a lower of cellulose were observed, but only at the highest level of inclusion $(150 \mathrm{~g} / \mathrm{kg})$.

\subsection{Dry matter and nitrogen flows}

The DM and $\mathrm{N}$ daily balances and the separation of faecal $\mathrm{N}$ in fractions for each of the experimental diets are shown in Table 6. Values are expressed per $\mathrm{kg}$ of metabolic weight to correct the increase of pig weight throughout the successive trial series and as $\mathrm{g} / \mathrm{g}$ total faecal $\mathrm{N}$ in the case of $\mathrm{N}$ fractionation.

A trend for an interaction $(P \leq 0.08)$ between source and level of inclusion of fibrous feeds was observed both on DM and $\mathrm{N}$ intake, faecal $\mathrm{N}$ and urine $\mathrm{N}$ excretion, as values tended to decrease with dietary level of inclusion for OP, but to increase in $\mathrm{CM}$ diets. When comparing with the $\mathrm{C}$ diet, the only significant differences observed were a higher faecal $\mathrm{N}$ excretion $(+54 \%)$ in the case of diet CM150 and a lower urine $\mathrm{N}$ excretion $(-23 \%)$ in the case of diet OP150. Daily $\mathrm{N}$ retention averaged $1.08 \mathrm{~g} / \mathrm{kg}^{0.75}$ ( $54.8 \%$ of mean $\mathrm{N}$ intake) and was not affected by any of the treatments studied.

Average proportions of UDN, BEDN and WSN on total faecal N excretion were, respectively, $0.139,0.574$ and 0.287 and were not affected by source or level of fibre. When comparisons were made against $C$ diet, the only differences that reached 
Effect of source $(S)$ and level $(L)$ of fibrous byproducts on faeces and urine composition (g/kg DM, unless otherwise specified).

\begin{tabular}{|c|c|c|c|c|c|c|c|c|c|}
\hline & \multicolumn{6}{|c|}{ Treatments ${ }^{a}$} & \multicolumn{3}{|c|}{ Significance } \\
\hline & Control & OP75 & OP150 & CM75 & CM150 & SEM $^{\mathrm{b}}$ & $S$ & $L$ & $S \times L$ \\
\hline \multicolumn{10}{|l|}{ Faeces } \\
\hline Dry matter $(g / \mathrm{kg})$ & 322 & 309 & 302 & 314 & 345 & 11.9 & 0.068 & 0.331 & 0.151 \\
\hline Organic matter ${ }^{c, d}$ & 833 & 836 & 837 & 847 & 862 & 3.0 & $<0.001$ & 0.022 & 0.034 \\
\hline Crude protein $^{\mathrm{e}, \mathrm{f}}$ & 179 & 200 & 229 & 197 & 205 & 5.8 & 0.065 & 0.014 & 0.131 \\
\hline NDICPC,g,h & 43.8 & 46.6 & 54.8 & 69.5 & 90.9 & 4.5 & 0.009 & 0.160 & 0.524 \\
\hline Ether extract ${ }^{\mathrm{e}}$ & 81.6 & 88.2 & 100 & 82.7 & 83.3 & 3.8 & 0.007 & 0.108 & 0.147 \\
\hline Total dietary fibre & 487 & 462 & 431 & 432 & 444 & 18.2 & 0.748 & 0.720 & 0.423 \\
\hline Soluble fibre ${ }^{\mathrm{i}}$ & 45.4 & 31.5 & 54.5 & 25.0 & 43.7 & 11.0 & 0.479 & 0.109 & 0.859 \\
\hline aNDFom & 478 & 473 & 423 & 476 & 492 & 14.5 & 0.003 & 0.120 & 0.005 \\
\hline ADFom ${ }^{c, g}$ & 216 & 215 & 196 & 255 & 325 & 6.6 & $<0.001$ & 0.002 & $<0.001$ \\
\hline $\mathrm{ADL}^{\mathrm{c}, \mathrm{g}}$ & 46.8 & 50.0 & 48.4 & 102 & 166 & 6.1 & $<0.001$ & 0.001 & 0.001 \\
\hline Hemicelluloses ${ }^{c, j}$ & 262 & 258 & 227 & 221 & 167 & 10.2 & $<0.001$ & $<0.001$ & 0.682 \\
\hline Cellulose $\mathrm{e}^{\mathrm{e}, \mathrm{f}, \mathrm{g}, \mathrm{k}}$ & 169 & 165 & 148 & 154 & 159 & 2.8 & 0.933 & 0.019 & $<0.001$ \\
\hline \multicolumn{10}{|l|}{ Urine } \\
\hline Dry matter $(g / k g)$ & 40.1 & 34.5 & 36.7 & 33.1 & 40.2 & 5.82 & 0.626 & 0.449 & 0.955 \\
\hline Total Kjeldahl N ${ }^{1}$ & 205 & 167 & 168 & 173 & 164 & 5.83 & 0.648 & 0.445 & 0.255 \\
\hline
\end{tabular}

a OP75 $=75 \mathrm{~g} / \mathrm{kg}$ orange pulp; OP150 $=150 \mathrm{~g} / \mathrm{kg}$ orange pulp; CM75 =75 g/kg carob meal; CM150=150 $\mathrm{g} / \mathrm{kg} \mathrm{carob} \mathrm{meal.}$

b Standard error of means $(n=6)$.

c Contrast control vs. CM150 $(P<0.01)$.

d Contrast control vs. CM $75(P<0.05)$.

e Contrast control vs. OP150 $(P<0.01)$.

f Contrast control vs. CM150 $(P<0.05)$.

$g$ Contrast control vs. CM $75(P<0.01)$.

h Neutral detergent insoluble crude protein.

i Calculated as TDF minus aNDFom corrected for protein.

$\mathrm{j}$ Calculated as the difference between NDF and ADF.

$k$ Calculated as the difference between ADF and ADL.

1 Contrast control vs. all fibrous by-products added diets $(P<0.05)$.

significant levels $(P<0.05)$ were the increments observed in the proportion of UDN and the decrease in that of WSN for the diets containing $\mathrm{CM}$.

\subsection{Slurry characteristics and gaseous emissions}

Water intake during the collection period was not affected by treatments, averaging $7.36 \pm 3.29$ (SD) $\mathrm{kg} /$ day. The initial slurry characteristics (DM, OM, TAN, TKN and VFA) did not differ significantly among the different fibre sources and levels

Table 6

Effects of source and level of fibrous by-products in the diet on daily DM and $\mathrm{N}$ balance and on the proportions of faecal $\mathrm{N}$ fractions.

\begin{tabular}{|c|c|c|c|c|c|c|c|c|c|}
\hline & \multicolumn{6}{|c|}{ Treatments $^{\mathrm{a}}$} & \multicolumn{3}{|c|}{ Significance } \\
\hline & Control & OP75 & OP150 & CM75 & CM150 & $\mathrm{SEM}^{\mathrm{b}}$ & $S$ & $L$ & $S \times L$ \\
\hline Mean body weight $(\mathrm{kg})$ & 107 & 107 & 106 & 105 & 109 & 1.64 & 0.820 & 0.415 & 0.091 \\
\hline \multicolumn{10}{|l|}{ DM balance $\left(\mathrm{g} / \mathrm{kg}^{0.75}\right)$} \\
\hline Intake & 72.9 & 71.3 & 68.3 & 65.7 & 77.1 & 3.8 & 0.724 & 0.326 & 0.082 \\
\hline Faeces $^{c}$ & 10.2 & 10.4 & 9.10 & 10.8 & 14.0 & 1.00 & 0.012 & 0.322 & 0.025 \\
\hline Urine & 2.78 & 3.05 & 2.70 & 2.79 & 3.15 & 0.17 & 0.725 & 0.892 & 0.063 \\
\hline \multicolumn{10}{|l|}{$N$ balance $\left(\mathrm{g} / \mathrm{kg}^{0.75}\right)$} \\
\hline Intake & 2.02 & 1.97 & 1.86 & 1.80 & 2.15 & 0.105 & 0.638 & 0.293 & 0.046 \\
\hline Faeces $^{c}$ & 0.297 & 0.341 & 0.338 & 0.341 & 0.458 & 0.030 & 0.081 & 0.097 & 0.064 \\
\hline Urined $^{d}$ & 0.584 & 0.553 & 0.448 & 0.462 & 0.508 & 0.031 & 0.538 & 0.517 & 0.029 \\
\hline Retained $^{\mathrm{e}}$ & 1.14 & 1.08 & 1.07 & 0.979 & 1.16 & 0.075 & 0.775 & 0.260 & 0.179 \\
\hline \multicolumn{10}{|c|}{$N$ fractions in faeces ( $g / g$ total faecal $N$ ) } \\
\hline $\mathrm{UDN}^{\mathrm{c}, \mathrm{f}, \mathrm{g}}$ & 0.088 & 0.130 & 0.134 & 0.165 & 0.178 & 0.026 & 0.146 & 0.681 & 0.948 \\
\hline BEDN $^{h}$ & 0.593 & 0.549 & 0.530 & 0.590 & 0.606 & 0.031 & 0.095 & 0.928 & 0.562 \\
\hline$W_{S N^{c, i}}$ & 0.318 & 0.321 & 0.336 & 0.245 & 0.216 & 0.023 & 0.229 & 0.540 & 0.578 \\
\hline
\end{tabular}

a $\mathrm{OP} 75=75 \mathrm{~g} / \mathrm{kg}$ orange pulp; $\mathrm{OP} 150=150 \mathrm{~g} / \mathrm{kg}$ orange pulp; $\mathrm{CM} 75=75 \mathrm{~g} / \mathrm{kg}$ carob meal; $\mathrm{CM} 150=150 \mathrm{~g} / \mathrm{kg}$ carob meal.

b Standard error of means $(n=6)$.

c Contrast control vs. CM150 $(P<0.05)$.

d Contrast control vs. OP150 $(P<0.05)$.

e Calculated as the difference between $\mathrm{N}$ intake and the sum of $\mathrm{N}$ in faeces $+\mathrm{N}$ in urine.

f Undigested dietary $\mathrm{N}$.

$g$ Contrast control vs. CM75 $(P<0.05)$

h Bacterial and endogenous debris $\mathrm{N}$.

i Water soluble $\mathrm{N}$. 
Table 7

Effect of source and level of fibrous by-products in the diet on slurry (faeces + urine) excretion, initial characteristics and derived ammonia $\left(\mathrm{NH}_{3}\right)$ emission and biochemical methane potential $\left(B_{0}\right)$.

\begin{tabular}{|c|c|c|c|c|c|c|c|c|c|}
\hline & \multicolumn{6}{|c|}{ Treatments $^{a}$} & \multicolumn{3}{|c|}{ Significance } \\
\hline & Control & OP75 & OP150 & CM75 & CM150 & $\mathrm{SEM}^{\mathrm{b}}$ & $S$ & $L$ & $S \times L$ \\
\hline Slurry excretion $(\mathrm{kg} / \mathrm{d})$ & 3.16 & 4.19 & 3.43 & 4.05 & 4.36 & 0.494 & 0.435 & 0.656 & 0.307 \\
\hline \multicolumn{10}{|l|}{ Slurry characteristics } \\
\hline $\mathrm{DM}(\mathrm{g} / \mathrm{kg})$ & 136.8 & 109.2 & 114.5 & 100.6 & 121.7 & 13.43 & 0.958 & 0.324 & 0.554 \\
\hline $\mathrm{OM}(\mathrm{g} / \mathrm{kg})$ & 108.7 & 87.3 & 91.9 & 82.0 & 99.9 & 10.97 & 0.899 & 0.305 & 0.541 \\
\hline Total ammonial $\mathrm{N}(\mathrm{g} / \mathrm{L})$ & 3.00 & 3.92 & 3.26 & 2.99 & 3.59 & 0.700 & 0.584 & 0.958 & 0.263 \\
\hline Total Kjeldahl N (g/kg) & 9.89 & 8.27 & 7.73 & 7.26 & 8.70 & 1.04 & 0.980 & 0.620 & 0.282 \\
\hline $\mathrm{pH}^{\mathrm{c}, \mathrm{d}}$ & 6.86 & 8.00 & 7.41 & 8.17 & 7.49 & 0.232 & 0.601 & 0.011 & 0.844 \\
\hline Total volatile fatty acids (mmol/L) & 68.13 & 84.8 & 78.1 & 67.1 & 73.8 & 9.20 & 0.242 & 0.989 & 0.459 \\
\hline Acetic acid (mmol/L) & 48.7 & 52.6 & 48.1 & 41.9 & 46.1 & 5.53 & 0.184 & 0.978 & 0.363 \\
\hline Propionic acid ( $\mathrm{mmol} / \mathrm{L}$ ) & 13.5 & 13.7 & 12.7 & 12.1 & 13.4 & 1.76 & 0.825 & 0.916 & 0.526 \\
\hline Butyric acid (mmol/L) & 8.10 & 10.6 & 10.10 & 8.50 & 11.2 & 1.56 & 0.759 & 0.482 & 0.308 \\
\hline \multicolumn{10}{|l|}{ Gas emissions } \\
\hline \multicolumn{10}{|l|}{ Ammonia emission assay } \\
\hline $\mathrm{g} \mathrm{NH}_{3} / \mathrm{kg}$ slurry $^{\mathrm{e}, \mathrm{f}, \mathrm{g}}$ & 2.44 & 1.84 & 1.64 & 1.76 & 1.99 & 0.205 & 0.409 & 0.973 & 0.135 \\
\hline $\mathrm{g} \mathrm{NH}_{3}-\mathrm{N} / \mathrm{kg}$ initial total Kjeldahl $\mathrm{N}^{\mathrm{e}}$ & 207 & 209 & 169 & 205 & 186 & 16.0 & 0.694 & 0.059 & 0.495 \\
\hline $\mathrm{mg} \mathrm{NH}_{3} /$ animal and day ${ }^{\mathrm{h}}$ & 840 & 812 & 597 & 783 & 839 & 82.0 & 0.221 & 0.357 & 0.124 \\
\hline \multicolumn{10}{|l|}{ Biochemical methane potential } \\
\hline$B_{0}, \mathrm{~mL}$ methane/g OM & 353 & 393 & 332 & 361 & 326 & 26.4 & 0.412 & 0.052 & 0.586 \\
\hline L methane/animal and day & 118 & 134 & 116 & 129 & 144 & 10.3 & 0.257 & 0.855 & 0.117 \\
\hline
\end{tabular}

a $\mathrm{OP} 75=75 \mathrm{~g} / \mathrm{kg}$ orange pulp; $\mathrm{OP} 150=150 \mathrm{~g} / \mathrm{kg}$ orange pulp; $\mathrm{CM} 75=75 \mathrm{~g} / \mathrm{kg}$ carob meal; $\mathrm{CM} 150=150 \mathrm{~g} / \mathrm{kg}$ carob meal.

b Standard error of means $(n=6)$.

${ }^{c}$ Contrast control vs. OP75 $(P<0.05)$.

d Contrast control vs. CM75 $(P<0.05)$.

e Cumulated (11 days).

${ }^{f}$ Contrast control vs. OP150 $(P<0.05)$.

$g$ Contrast control vs. all fibrous by-products added diets $(P<0.05)$.

h 24 -h $\mathrm{NH}_{3}$ emission from the slurry produced by one animal in 1 day.

tested (Table 7), although $\mathrm{pH}$ decreased (from 8.08 to 7.45 in average, $P=0.011$ ) with dietary fibre level. Ammonia emission from slurry $\left(\mathrm{g} \mathrm{NH}_{3} / \mathrm{kg}\right.$ slurry) was not affected by the source and level of dietary fibre. A trend $(P=0.059)$ was observed for a lower proportion of $\mathrm{N}-\mathrm{NH}_{3}$ emitted per $\mathrm{kg}$ of initial $\mathrm{TKN}$ in the slurries with a higher inclusion of fibrous by-products independently of the fibre source. Otherwise, $\mathrm{CH}_{4}$ potential tended to be lower $(P=0.052)$ in slurries from animals fed the highest fibre levels independently of the fibre source.

When slurry characteristics and the derived gaseous emission in the fibrous treatments were compared with treatment $\mathrm{C}, \mathrm{NH}_{3}$ emission per $\mathrm{kg}$ of slurry was lower $(P<0.05)$ in treatment OP150. Otherwise, when analyzed together, $\mathrm{NH}_{3}$ emission per kg of slurry decreased significantly in all the fibre-supplemented diets with respect to the control (from 2.44 to $1.81 \mathrm{~g}$, $P<0.05$ ).

Fig. 1 shows the evolution of the cumulated $\mathrm{CH}_{4}$ emission with time in the $B_{0}$ assay. On Days 1 and 3 , the slurry from treatments OP75 and OP150 produced higher $(P<0.05)$ amounts of $\mathrm{CH}_{4}$ than the rest of treatments. On Days 6 and $8, \mathrm{CH}_{4}$

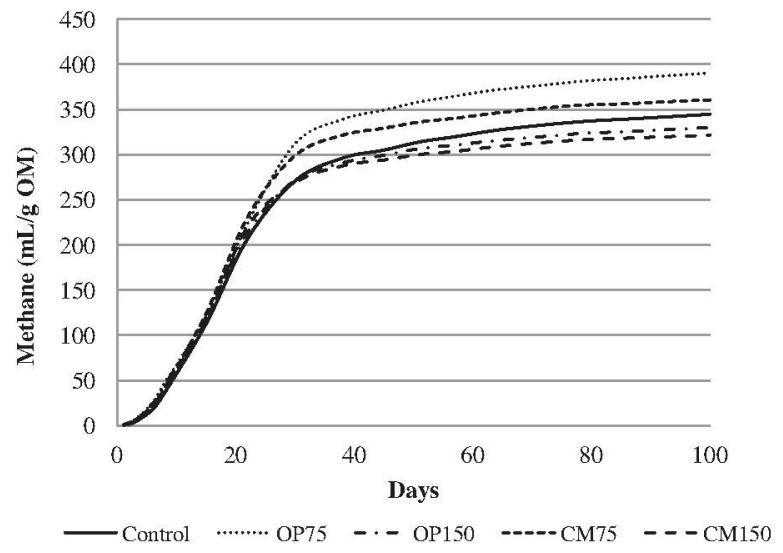

Fig. 1. Effect of diets on cumulated methane emission potential from slurry over 100 days ( $\mathrm{SD}=21.0 \mathrm{~mL} / \mathrm{g} \mathrm{OM})$. Treatments are: $\mathrm{OP} 75=75 \mathrm{~g} / \mathrm{kg}$ orange pulp; $O P 150=150 \mathrm{~g} / \mathrm{kg}$ orange pulp; $\mathrm{CM} 75=75 \mathrm{~g} / \mathrm{kg}$ carob meal; $\mathrm{CM} 150=150 \mathrm{~g} / \mathrm{kg}$ carob meal. Mean values of $O P 75$ and $O P 150$ were greater $(P<0.05)$ than the others on Days 1 and 3. On Days 6 and $8, \mathrm{CH}_{4}$ levels of OP75 were higher $(P<0.05)$ than control and no different from the others. From Day 45 OP75 was higher than $\mathrm{CM} 150(P<0.05)$. 
levels of OP75 diet were higher $(P<0.05)$ than control diet, but not different from the others. Beyond Day 45, cumulated $\mathrm{CH}_{4}$ production from OP75 slurries was significantly higher than that of CM150 $(P<0.05)$ and tended to be different from OP150 $(P=0.07)$ but not from $C$ and CM75. No significant interaction was detected between treatments and time.

\section{Discussion}

In the current study, dietary soluble fibre proportions increased in parallel to OP (from 61.2 in the $\mathrm{C}$ to $97.3 \mathrm{~g} / \mathrm{kg} \mathrm{DM}$ in the OP150 diet), and those of ADL to CM inclusion level (from 8.0 in the $C$ to $33.9 \mathrm{~g} / \mathrm{kg}$ DM in CM150 diet).

The dietary changes implied small variations in DM intake $\left(\mathrm{g} / \mathrm{kg}^{0.75}\right)$ that decreased (by 6.31\%) in the OP150 and increased (by 5.76\%) in the CM150 diet in respect to $C$ diet. This effect is in accordance with former results (Glitsø et al., 1998; Wenk, 2001) of an opposite influence of soluble and insoluble fibre on transit time and satiety. Additionally, these differences in the cell wall constituents implied significant changes of NDF digestibility, which increased with OP addition (by $12.8 \%$, between $\mathrm{C}$ and OP150 diets), but decreased in parallel to CM level (by 8.57 and $21.9 \%$ in diets CM75 and CM150 diets, respectively). As reported by previous works in pigs (Graham et al., 1986; Chabeauti et al., 1991; Bach Knudsen and Hansen, 1991; Bach Knudsen et al., 1993), cell wall digestibility depends on its degree of lignification, as lignin makes more difficult the microbial degradation of other potentially fermentable cell wall constituents. Otherwise, soluble fibre was extensively fermented in all the experimental diets of the current study, which agrees with previous works in pigs (Graham et al., 1986; Bach Knudsen et al., 1993; Canibe and Bach Knudsen, 1997; Glitsø et al., 1998). In all, changes in dietary composition and differences in NDF digestibility resulted in an increase of the amount of total fibre fermented (digestible aNDFom + digestible soluble fibre) in parallel to OP inclusion (from 124 in the C diet to 144 and $174 \mathrm{~g} / \mathrm{kg} \mathrm{DM}$ in 75 and 150 OP diets, respectively), but in little effect of CM level of substitution (122 and $118 \mathrm{~g} / \mathrm{kg}$ DM for 75 and $150 \mathrm{CM}$ diets).

Proportion of ADL in faecal DM increased in parallel to CM inclusion (from $46.8 \mathrm{~g} / \mathrm{kg}$ in the C diet to 102 and $166 \mathrm{~g} / \mathrm{kg}$ in CM75 and CM150 diets, respectively). As a consequence, a less degradable OM content in the slurry from CM diets should be expected. According to Angelidaki and Sanders (2004), lignin and cellulose has a relatively lower $\mathrm{CH}_{4}$ potential emission than other organic constituents, whereas fat and proteins have the highest. According to Triolo et al. (2011) lignin concentration in $\mathrm{OM}$ is the strongest predictor of $B_{0}$ in substrates due to their high negative correlation. In the same way, Beccaccia et al. (2015) found a significant positive effect of NDF, but negative of ADL concentration in the slurry on potential $\mathrm{CH}_{4}$ emissions. Contrary to expected, in the present study, the $B_{0}$ tended to be lower in the diets with the highest fibrous by-products inclusion level $(150 \mathrm{~g} / \mathrm{kg})$, independently of the source of fibre. Different mechanisms might be responsible of this reduction in $\mathrm{CH}_{4}$ production with the inclusion of by-products. Unlike faeces from animals fed OP, faeces from animals fed CM contained higher contents of non-degradable material such as NDICP and lignin that could explain this lower $B_{0}$. In the case of OP, although slurries from treatments OP150 and OP75 produced higher amounts of $\mathrm{CH}_{4}$ at the beginning of the batch assay, the accumulated production early started to stabilize in treatment OP150 (Fig. 1). However, slurries from treatment OP75 continued producing higher amounts of $\mathrm{CH}_{4}$ on Day 45. The degradation of OM into $\mathrm{CH}_{4}$ is a biological process which is sensitive to inhibitors such as VFA and free $\mathrm{NH}_{3}$ (Chen et al., 2008; Vedrenne et al., 2008). Within the complexity of methanogenesis it is known that in anaerobic digestion, the inclusion of excessive amounts of highly degradable materials such as industrial orange wastes can inhibit methanogens due to accumulation of VFAs and a decrease in digester pH (Kaparaju and Rintala, 2006; Chen et al., 2008). Finally, no clear relationship between effluent $\mathrm{EE}$ and potential $\mathrm{CH}_{4}$ emissions could be detected. Although CTTAD of EE was higher at the highest levels of inclusion of fibre, EE content of diets was also higher, which may have diluted the effects of treatments in slurry composition. Also, EE content in faeces was affected by fibre source but not by fibre level, whereas $B_{0}$ tended to be lower at the highest fibre inclusion level, regardless the fibre source. For this reason, it seems that in this study fat content had no direct effect on $\mathrm{CH}_{4}$ emissions and fibre composition may be the most relevant factor. Then, it seems that, the slurry from treatment OP75 was the one that offer the best conditions in terms of the equilibrium between the degradable and non-degradable OM for $\mathrm{CH}_{4}$ yield. Not only $\mathrm{B}_{0}$ but also the amount of $\mathrm{OM}$ excreted per pig is determinant on the impact of $\mathrm{CH}_{4}$ in pig production. In this way, expressed per pig and day, $\mathrm{CH}_{4}$ production in the present experiment did not differ among the experimental diets.

Faecal CP digestibility decreased with level of incorporation of both fibrous by-products compared to $\mathrm{C}$ diet. This result might be explained by the high proportion of NDICP in the OP and CM samples used in the current work ( 0.515 and 0.369 , respectively) and agree with the low $\mathrm{CP}$ digestion efficiencies assigned to these ingredients for growing pigs in different international feed tables (from 0.35 to 0.57; INRA, 2002; CVB, 2004; FEDNA, 2010). Additionally, digestibility of CP of OP in the whole digestive tract is relatively low even in ruminants (from 0.422 to 0.757; Bampidis and Robinson, 2006), which might be related to the formation of Maillard compounds during the drying of these feeds. These effects on CP digestibility when NDF in the $C$ diet was replaced with more fermentable or lignified sources of fibre led to an increase of faecal CP excretion on DM. At the same time, $\mathrm{N}$ concentration in urine DM decreased in all the experimental diets with respect to $\mathrm{C}$ $(P<0.05)$.

The inclusion of soluble fibre led to a decrease of urine: faecal $\mathrm{N}$ ratio (from 2.0 in the $\mathrm{C}$ to 1.3 in the OP 150 diet), which agrees with previous works (Canh et al., 1997; Zervas and Zijlstra, 2002a; Bindelle et al., 2009; Heimendahl et al., 2010). This effect has been generally explained by an increase in the amount of $\mathrm{N}$ used for microbial protein synthesis in the hindgut, which is excreted in faeces (organic $\mathrm{N}$ ) instead of in urine (urea N). However, in the current study, BEDN proportion in total 
faecal $\mathrm{N}$ tended to be lower when a higher proportion of highly fermentable fibre was given in OP diets. Previous works (Kreuzer et al., 1999; Heimendahl et al., 2010) measured faecal $\mathrm{N}$ fractions in pigs using the same methodology than in the current study. In these studies, a significant decrease of BEDN proportion in total faecal $\mathrm{N}$ was observed with soluble fibre supplementation, but daily faecal N and BEDN excretion increased, because highly fermentable sources of fibre (as citrus or sugar beet pulp) replaced starch in the experimental feeds, so that dietary NDF content increased in parallel to by-products inclusion. Consequently, differences in supply of soluble fibre among diets were great and led to a significant increase of DM and $\mathrm{N}$ intake. However, when citrus and beet pulp were added to diets with similar NDF levels, little effect of inclusion of soluble fibre on daily BEDN excretion was also reported (Kreuzer et al., 1999; experiment 1). In the same way, several works (Graham et al., 1986; Bach Knudsen et al., 1993; Glitsø et al., 1998) have demonstrated that a significant proportion of the dietary soluble fibre (from 0.20 to 0.40 ) is fermented before the ileum, and so it would not be a direct substrate for hindgut microbial population. Then the suggested effect of the fermentable fibre in the diet on microbial $\mathrm{N}$ should be revised.

When more insoluble sources of fibre were used, other research shows discrepancies with respect to its effect on urine: faecal N ratio. In some studies (Zervas and Zijlstra, 2002b; Bindelle et al., 2009) inclusion of oat hulls in the diet did not reduce this ratio, whereas others (Galassi et al., 2010; Jarret et al., 2012) adding, respectively, wheat bran or dry distillers grains and solubles, reported a significant decrease (by 33.5 or $46.4 \%$, respectively). In the current study, CM addition also reduced urine: faecal $\mathrm{N}$ ratio (from 2.0 in the $\mathrm{C}$ with respect to 1.3 and 1.1 in the CM 75 and 150 diets, respectively), which was more related to a greater faecal than to a lesser urine excretion. Inclusion of CM did not either affect proportion of BEDN in total faecal N, although daily BEDN excretion increased in diet CM 150 with respect to C diet, because of a higher faecal DM excretion.

The results from the current study also indicate that part of the increment in total faecal $\mathrm{N}$ excretion with both sources of fibre was due to UDN, especially in the case of CM diets, in parallel to the increased amount of CP bounded to NDF in fibrous by-products feeds. This result agrees with that obtained by Heimendahl et al. (2010), where the increase of UDN fraction with sugar beet pulp supplementation explained a greater proportion of the increment of total faecal N than BEDN. Fraction WSN in faeces has been associated (Кreuzer et al., 1999; Heimendahl et al., 2010) to endogenous N losses (i.e. enzyme secretions, bacteria lysed before excretion, mechanical erosion of mucosa), although average UDN excretion in the current study $(1.44 \mathrm{~g} / \mathrm{kg} \mathrm{DMi}$ ) was below the general value (1.89) established by Jansman et al. (2002). Some studies have reported that high fibre diets might increase endogenous $\mathrm{N}$ losses (Souffrant, 2001), but differences in ileal endogenous $\mathrm{N}$ flow again became no significant when iso-NDF diets containing various fibre sources were compared (Schulze et al., 1995, experiment 2).

A low urine: faecal $\mathrm{N}$ ratio is associated with a low $\mathrm{NH}_{3}$ emission from the slurry, reducing the environmental load of pig facilities (Nahm, 2003). In the present study, at a fixed temperature, the most important factors related to $\mathrm{NH}_{3}$ emission were $\mathrm{pH}$ and the form and content of $\mathrm{N}$. Total Kjeldahl $\mathrm{N}$ and TAN concentration in the slurry were not different among treatments. However, as indicated, urine $\mathrm{N}$ content and urine: faecal $\mathrm{N}$ ratio was lower in the fibrous diets than in $\mathrm{C}$ diet. Consequently, all fibrous diets showed a lower $\mathrm{NH}_{3}$ emission per $\mathrm{kg}$ of slurry than $\mathrm{C}$ diet. From all the fibrous diets, OP150 showed the lowest $\mathrm{NH}_{3}$ emission compared to the control diet. Kreuzer et al. (1998) also showed that feeds with high contents in pectin and hemicellulose, like citrus pulp and sugar beet pulp, were the most effective fibre sources to reduce $\mathrm{N}$ loss in manure, as compared to cellulose from rye bran and cassava.

Additionally, the lowest proportion of $\mathrm{N}^{-\mathrm{NH}_{3}}$ with respect to the initial TKN was observed in treatments OP150 and CM150 (0.169 and 0.186, respectively). The slurry from the rest of treatments (including C) lost approximately 0.210 of the initial $\mathrm{N}$ as $\mathrm{N}-\mathrm{NH}_{3}$. Similarly, Sutton et al. (1999) reported losses of 0.140 and 0.237 of the initial $\mathrm{N}$ as $\mathrm{N}-\mathrm{NH}_{3}$ in sugar beet pulp and grain based diets, respectively, over a 7-day volatilization study. This means that the $\mathrm{N}$ contained in the slurries with a higher inclusion of fibrous by-products had a lower volatilization potential probably due to both, the lower urine: faecal N ratio and its lower pH. Contrary to the results obtained by Canh et al. (1998c) and Jarret et al. (2012), in the present study, the inclusion of fermentable fibre did not cause significant differences on VFA of slurry. In agreement with the faecal $\mathrm{N}$ fractionation analyses, bacterial activity seems not to be especially relevant in OP diets compared to the other diets. However, slurry $\mathrm{pH}$ was significantly lower in the diets including $150 \mathrm{~g} / \mathrm{kg}$ of OP or CM compared to the diets including $75 \mathrm{~g} / \mathrm{kg}$, thus indicating that in this case, slurry pH does depend more on the level than on the source of fibre and that, as Canh et al. (1998c) suggested, other factors in addition to VFA can be related with pH changes. These other factors might include carbonate concentrations of the slurry (Wellinger, 1985; Sommer and Husted, 1995).

\section{Conclusions}

In all, our results suggest that the changes induced in effluent composition by differences in dietary fibre composition affected the $B_{0}$ and $\mathrm{NH}_{3}$ potential emission from slurry. Both, the supply of lignocellulosic material in $\mathrm{CM}$ diets and of highly fermentable fibre in OP diets affected negatively $B_{0}$ at the highest level of inclusion $(150 \mathrm{~g} / \mathrm{kg})$. Results also indicate that effects of source of fibre on faecal $\mathrm{N}$ constituents are complex and cannot be only explained by the influence of dietary fibre on microbial CP synthesis in the hindgut. The changes observed led to a less degradable $\mathrm{N}$ content in the slurry from feeds including both types of fibrous by-products, with an increase in the proportion of faecal CP excreted as NDICP and a decrease of the urine: faecal $\mathrm{N}$ ratio. As a result, $\mathrm{NH}_{3}$ emission from slurries of animals fed diets including both types of fibrous by-products were lesser than in the control diet. 


\section{Conflict of interest}

All authors disclose not to have any actual or potential conflict of interest including any financial, personal or other relationship with other people or organizations on the submitted work that could inappropriately influence, or be perceived to influence, their work.

\section{Acknowledgements}

This project was funded by the Spanish Ministry of Science and Innovation (AGL2011-30023) and the Valencian Government (ACOMP/2013/118). We also thank CAPES Foundation, Ministry of Education of Brazil, Brasilia - DF 70040-020, Brazil for a research fellowship grant.

\section{References}

Angelidaki, I., Sanders, W., 2004. Assessment of the anaerobic biodegradability of macropollutants. Rev. Environ. Sci. Biotechnol. 3, $117-129$.

Angelidaki, I., Alves, M., Bolzonella, D., Borzacconi, L., Campos, J.L., Guwy, A.J., Kalyuzhnyi, S., Jenicek, P., van Lier, J.B., 2009. Defining the biomethane potential (BMP) of solid organic wastes and energy crops: a proposed protocol for batch assays. Water Sci. Technol, 59, $927-934$.

AOAC, 2000. Official Methods of Analysis, 17th ed. Association of Official Analytical Chemists, Washington, DC, USA.

APHA, 2005. Standard Methods for the Examination of Water and Wastewater, Centennial ed. APHA, Baltimore, Maryland.

Bach Knudsen, K.E., Hansen, I., 1991. Gastrointestinal implications in pigs of wheat and oat fractions. Br. J. Nutr. 65, $217-232$.

Bach Knudsen, K.E., Jensen, B.B., Hansen, I., 1993. Digestion of polysaccharides and other major components in the small and large intestine of pigs fed on diets consisting of oat fractions rich in $\beta$-D-glucan. Br. J. Nutr. 70, 537-556.

Bampidis, V.A., Robinson, P.H., 2006. Citrus by-products as ruminant feeds: a review. Anim. Feed Sci. Technol. $128,175-217$.

Beccaccia, A., Ferrer, P., Ibáñez, M.A., Estellés, F., Rodríguez, C., Moset, V., De Blas, C., Calvet, S., García-Rebollar, P., 2015. Relationships among slurry characteristics and gaseous emissions at different types of commercial Spanish pig farms. Span. J. Agric. Res. 13, e06-002.

Bindelle, J., Buldgen, A., Delacollette, M., Wavreille, J., Agneessens, R., Destain, J.P., Leterme, P., 2009. Influence of source and concentrations of dietary fiber on in vivo nitrogen excretion pathways in pigs as reflected by in vitro fermentation and nitrogen incorporation by fecal bacteria. J. Anim. Sci. 87 , $583-593$.

Canh, T.T., Verstegen, M.W.A., Aarnink, A.J.A., Schrama, J.W., 1997. Influence of dietary factors on nitrogen partitioning and composition of urine and faeces of fattening pigs. J. Anim. Sci. 75, 700-706.

Canh, T.T., Aarnink, A.J.A., Schutte, J.B., Sutton, A., Langhout, D.J., Verstegen, M.W.A., 1998a. Dietary protein affects nit rogen excretion and ammonia emission from slurry of growing finishing pigs. Livest. Prod. Sci. 56, 181-191.

Canh, T.T., Aarnink, A.J.A., Verstegen, M.W.A., Schrama, J.W., 1998b. Influence of dietary factors on the pH and ammonia emission of slurry from growing-finishing pigs. J. Anim. Sci. 76, 1123-1130.

Canh, T.T., Sutton, A.L., Aarnink, A.J.A., Verstegen, M.W.A., Schrama, J.W., Bakker, G.C.M., 1998c. Dietary carbohydrates alter the fecal composition and pH and the ammonia emission from slurry of growing pigs. J. Anim. Sci. 76, 1887-1895.

Canibe, N., Bach Knudsen, K.E., 1997. Digestibility of dried and toasted peas in pigs. 1. Ileal and total tract digestibilities of carbohydrates. Anim. Feed Sci. Technol. 64, 293-310.

Chabeauti, E., Noblet, J., Carré, B., 1991. Digestion of plant cell walls from four different sources in growing pigs. Anim. Feed Sci. Technol. $32,207-213$.

Chen, Y., Cheng, J.J., Creamer, K.S., 2008. Inhibition of anaerobic digestion process: a review. Bioresour. Technol. 99, 4044-4064.

CVB, 2004. Veevoedertabel (Livestock Feed Table). CentraalVeevoeder Bureau, Lelystad, The Netherlands.

Dinuccio, E., Berg, W., Balsari, P., 2008. Gaseous emissions from the storage of unt reated slurries and the fractions obtained after mechanical separation. Atmos, Environ. 42, 2448-2459.

FAO, 2013. Mitigation of greenhouse gas emissions in livestock production. A review of technical options for non-CO 2 emissions. In: Gerber, P.J., Henderson, B., Makkar, H.P.S. (Eds.), FAO Animal Production and Health Paper No. 177. FAO, Rome, Italy.

FEDNA, 2006. In: De Blas, C., Gasa, J., Mateos, G.G. (Eds.), Necesidades nutricionales para ganado porcino: normas FEDNA. Fundación Española para el Desarrollo de la Nutrición Animal, Madrid, Spain, 55 pp.

FEDNA, 2010. In: de Blas, C., Mateos, G.G., García-Rebollar, P. (Eds.), Tablas FEDNA de composición y valor nutritivo de alimentos para la fabricación de piensos compuestos., 3rd ed. Fundación Española para el Desarrollo de la Nutrición Animal, Madrid, Spain, 502 pp.

Galassi, G., Colombini, S., Malagutti, L., Crovetto, G.M., Rapetti, L., 2010. Effects of high fiber and low protein diets on performance, digestibility, nitrogen excretion and ammonia emission in the heavy pig. Anim. Feed Sci. Technol. 161, 140-148.

Glitsø, L.V., Brunsgaard, G., Højsgaard, S., Sandström, B., Bach Knudsen, K.E., 1998. Intestinal degradation in pigs of rye dietary fibre with different structural characteristics. Br. J. Nutr. 80, 457-468.

Graham, H., Hesselman, K., Aman, P., 1986. The influence of wheat bran and sugar beet pulp on the digestibility of dietary components in a cereal-based pig diet. J. Nutr. 116, 242-251.

Heimendahl, E., Breves, G., Abel, H.J., 2010. Fiber-related digestive process in three different breeds of pigs. J. Anim. Sci. $88,972-981$.

INRA, 2002. Valeursnutritives pour les volaillles. In: Sauvant, D., Perez, J.M., Tran, G. (Eds.), Tables de composition et de valeur nutritive des matières premiéres destinées aux animaux d'élevage. INRA Editions, Paris Cedex, France.

Jansman, A.J.M., Smink, W., van Leeuwen, P., Rademacher, M., 2002. Evaluation through literature data of the amount and amino acid composition of basal endogenous crude protein at the terminal ileum of pigs. Anim. Feed Sci. Technol. 98, 49-60.

Jarret, G., Martinez, J., Dourmad, J.Y., 2011. Effect of biofuel co-products in pig diets on the excretory patterns of $\mathrm{N}$ and $\mathrm{C}$ on the subsequent ammonia and methane emissions from pig effluent. Animal 5, 622-631.

Jarret, G., Cerisuelo, A., Peu, P., Martinez, J., Dourmad, J.Y., 2012. Impact of pig diets with different fiber contents on the composition of excreta and their gaseous emissions and anaerobic digestion. Agric. Ecosyst. Environ. 160, 51-58.

Jouany, J.P., 1982. Volatile fatty acid and alcohol determination in digestive contents, silage juices, bacterial cultures and anaerobic fermentor contents. Sci. Aliment. 2, 131-144.

Kaparaju, P.L.N., Rintala, J.A., 2006. Thermophilic anaerobic digestion of industrial orange waste. Environ. Technol. $27,623-633$.

Kreuzer, M., Roth, F.M., Kirchgessner, M., 1989. Mikrobielle umsetzungen im enddarm von sauen bei intracaecaler infusion hoher Mengen an verschiedenen reinen substraten. 1. Veränderung der Verdaulichkeit von Stickstoff und Aminosäuren. Landwirtsch. Forsch. 42, 72 -92.

Kreuzer, M., Machmüller, A., Gerdemann, M.M., Hanneken, H., Wittmann, M., 1998. Reduction of gaseous nitrogen loss from pig manure using feeds rich in easily-fermentable non-starch polysaccharides. Anim. Feed Sci. Technol. 73, 1-19.

Kreuzer, M., Wittmann, M., Gerdemann, M.M., Hanneken, H., Abel, H., Machmuller, A., 1999. Re-examination of the metabolizable energy contents of various rations containing different types and levels of bacterially fermentable substrates in digestibility experiments with growing pigs. J. Anim. Physiol. Anim. Nutr. 82, 33-49. 
Licitra, G., Hernández, T.M., Van Soest, P.J., 1996. Standardization of procedures for nitrogen fractionation of ruminant feed. Anim. Feed Sci. Technol. 57, 347-358.

Mertens, D.R., 2002. Gravimetric determination of amylase-treated neutral detergent fibre in feeds with refluxing beakers or crucibles: collaborative study. J. AOAC Int. 85, 1217-1240.

Møller, H.B., Sommer, S.G., Ahring, B.K., 2004a. Methane productivity of manure, straw and solid fractions of manure. Biomass Bioenergy $36,485-495$.

Møller, H.B., Sommer, S.G., Ahring, B.K., 2004b. Biological degradation and greenhouse gas emissions during pre-storage of liquid animal manure. J. Environ. Qual. 33, 27-36.

Nahm, K.H., 2003. Influences of fermentable carbohydrates on shifting nitrogen excretion and reducing ammonia emission of pigs. Crit. Rev. Environ. Sci. Technol. 30, 135-186.

Ndegwa, P.M., Hristov, A.N., Joo, H.S., 2009. Measuring concentrations of ammonia in ambient air or exhaust air stream using acid traps. J. Environ. Qual. $38,647-653$.

SAS Institute, 2008. SAS/STAT ${ }^{\circledR}$ User's Guide. Version 9.3. SAS Institute, Inc., Cary, NC.

Schulze, H., van Leeuwen, P., Verstegen, M.W.A., Van der Berg, J.W.O., 1995. Dietary level and source of neutral detergent fiber and ileal endogenous nitrogen flow in pigs. J. Anim. Sci. 73, 441-448.

Sommer, S.G., Husted, S., 1995. A simple model of pH in slurry. J. Agric. Sci. 124, 447-453.

Souffrant, W.B., 2001. Effect of dietary fibre on ileal digestibility and endogenous nitrogen losses in the pig. Anim. Feed Sci. Technol. 90, 93-102.

Sutton, A.L., Kephart, K.B., Verstegen, M.W.A., Canh, T.T., Hobbs, P.J., 1999. Potential for reduction of odorous compounds in swine manure through diet modification. J. Anim. Sci. 77, 430-439.

Triolo, J.M., Sommer, S.G., Møller, H.B., Weisbjerg, M.R., Jiang, X.Y., 2011. A new algorithm to characterize biodegradability of biomass during anaerobic digestion: influence of lignin concentration on methane production potential. Bioresour. Technol. 102, 9395-9402.

Van Soest, P.J., Robertson, J.B., Lewis, B.A., 1991. Methods for dietary fiber, neutral detergent fiber and nonstarch polysaccharides in relation to animal nutrition. J. Dairy Sci. 74, 3583-3597.

Vedrenne, F., Béline, F., Daberta, P., Bernet, N., 2008. The effect of incubation conditions on the laboratory measurement of the methane producing capacity of livestock wastes. Bioresour. Technol. 99, 146-155.

Wellinger, A., 1985. Process parameters affecting methane production in mesophilic farm digesters. Biochem. J. 20, 131-137.

Wenk, G., 2001. The role of dietary fibre in the digestive physiology of the pig. Anim. Feed Sci. Technol. 90, 21-33.

Zervas, S., Zijlstra, R.T., 2002a. Effects of dietary protein oat hull fiber on nitrogen excretion patterns and postprandial plasma urea profiles in grower pigs. J. Anim. Sci. 80, 3238-3246.

Zervas, S., Zijlstra, R.T., 2002b. Effects of dietary protein and fermentable fiber on nitrogen excretion patterns and plasma urea in grower pigs. J. Anim. Sci. $80,3247-3256$. 